Original Research

\title{
Factors Correlated with the Intention of Iron Tablet Consumption among Female Adolescents
}

\section{Riri Aprianti ${ }^{1}$, Gadis Meinar Sari ${ }^{1}$ and Tiyas Kusumaningrum $^{2}$}

1 Faculty of Medicine Universitas Airlangga, Surabaya, Indonesia

2 Faculty of Nursing Universitas Airlangga, Surabaya, Indonesia

\begin{abstract}
Introduction: Anaemia in female adolescents tends to have a negative impact that is likely to later arise in pregnancy, labour and childbirth. The prevalence of iron deficiency anaemia in female adolescents in Indonesia is thirty percent. Indonesia runs an iron tablet program for female adolescents. However, with the running of the program, it is not clear what factors are correlated with the intention of iron tablet consumption among female adolescents. The purpose of this study was to analyse the factors correlated with the intention of iron tablet consumption among female adolescents.
\end{abstract}

Methods: This research used a cross-sectional design. The sample consisted of 100 students in senior high school in Surabaya, chosen by proportional random sampling. The independent variables were parent income, knowledge, perceived susceptibility, perceived seriousness, perceived threats, perceived benefits, perceived barriers, and perceived self-efficacy. The dependent variable was female adolescent intention related to consuming iron tablets. The data was collected using a questionnaire and analysed by a chi square test with a level of significance $\alpha<0.05$.

Results: There was a significant correlation between perceived threat $(p=0.02)$, perceived benefit $(p=0.01)$, perceived barrier $(p=0.02)$ and perceived self-efficacy $(p=0.00)$ and female adolescent intention related to consuming iron tablets. There was no correlation between parental income, adolescent knowledge, perceived susceptibility, and perceived seriousness with the intention to consume iron tablets.

Conclusion: From this research, it has been concluded that the factors related to the intention to consume iron tablets in female adolescents were perceived threat, perceived benefit, perceived barrier and perceived self-efficacy. Increasing the confidence of female adolescents in association with the importance of avoiding anaemia by consuming iron tablets is crucial so then they can maintain their health and prevent diseases due to anaemia later on.

\section{ARTICLE HISTORY}

Received: May 18, 2018

Accepted: August 08, 2018

\section{KEYWORDS}

anaemia; iron deficiency; adolescent; belief; self efficacy

\section{CONTACT}

Tiyas Kusumaningrum $\triangle$ tiyas-k@fkp.unair.ac.id $\equiv$ Faculty of Nursing Universitas Airlangga, Surabaya, Indonesia

Cite this as: Aprianti, R., Sari, G., \& Kusumaningrum, T. (2018). Factors Correlated with the Intention of Iron Tablet Consumption among Female Adolescents. Jurnal Ners, 13(1). 122-127. doi:http://dx.doi.org/10.20473/in.v13i1.8368

\section{INTRODUCTION}

Young women are a human resource that will give birth to the future generations of the nation. A phenomenon occurs in Indonesia where there is a high prevalence of iron deficiency anaemia in adolescent girls, at 30\% (WHO 2011). Anaemia is a problem that must be overcome in young women, because if it continues until pregnancy, labour and childbirth, then it can increase the risk of bleeding in maternal labour and postpartum women. It can also directly increase the risk of maternal mortality
(KEMENKES RI 2017). The high prevalence of iron deficiency anaemia in Indonesian young women has resulted in Indonesia being mandated by the World Health Organisation (WHO) to run an anaemia prevention program. The program provides iron tablets for girls aged 12-18 years old[9] (KEMENKES RI 2014). The provision of iron tablets is at the minimum dose of $60 \mathrm{mg}$ elemental iron and $0.4 \mathrm{mg}$ of folic acid at a dose of once a week, increasing to once a day during menstruation (KEMENKES RI 2014). One of the main targets of the National Medium-Term Development Plan (RPJMN) 2015 - 
2019 in Indonesia is an indicator of community nutrition improvement, one of which is the provision of iron supplements (TTD) for young women with a target of $30 \%$ by 2019 (Kementrian PPN/BPPN 2014). The access to the program by girls in school (junior high school and senior high school) is a good alternative choice (WHO 2011). An anaemia prevention program in Surabaya senior high school has been implemented since October 2017, however it was not known how far the intention was of the young women willing to consume the tablets. According to the Health Belief Model (HBM) theory, human intention for their personal health behavioural action is a result of a combination of individual beliefs (perceived susceptibility, perceived seriousness, perceived threat, perceived benefit, perceived barrier, and self efficacy), modifying factors (socioeconomic, knowledge, age, gender, ethnicity and personality), and cues for action (Glanz et al. 2015). This study aims to analyse the factors associated with the intention of female adolescents to consume iron tablets as an anaemia prevention effort by using the theory of the Health Belief Model.

\section{MATERIALS AND METHODS}

The design used in this research study was a crosssectional approach. The research was done in a high school located in central Surabaya. This high school is one of the high schools that have implemented an anaemia prevention programs for female students. This research used the proportional random sampling technique. The sample size was based on calculations, resulting in 100 participants. There were 20 classes in the senior high school where the research was conducted, so the proportion of the total samples related to each class resulted in 5 people. The independent variables in this study were the parents' income, knowledge, perceived susceptibility, perceived seriousness, perceived threats, perceived benefits, perceived barriers and perceived self efficacy. The dependent variable was the intention of female adolescents to consume iron tablets. The data was collected using a questionnaire. The questionnaire was adapted from Annisa and Nurmala's (2018) study. There were 54 questions in the questionnaire that consisted of questions about social economy (parents income), 10 questions about their knowledge of anaemia and iron tablets and questions on perceived susceptibility, perceived seriousness, perceived threats, perceived benefits, perceived barriers, perceived self efficacy, information sources and the intention to consume iron tablets. Each participant filled out the questionnaire themselves. The research team was in charge of ensuring that the participants understood the content of the questionnaire and answered it completely. The data was then analysed using a chi square test with a level of significant $\alpha=0.05$. The statistical software used was SPSS.

\section{RESULTS}

Table 1. Participants characteristic

\begin{tabular}{|c|c|c|}
\hline $\begin{array}{l}\text { Participants } \\
\text { characteristic }\end{array}$ & Number & Percentage \\
\hline \multicolumn{3}{|l|}{ Age: } \\
\hline 14 & 2 & $2 \%$ \\
\hline 15 & 33 & $33 \%$ \\
\hline 16 & 53 & $53 \%$ \\
\hline 17 & 12 & $12 \%$ \\
\hline Total & 100 & $100 \%$ \\
\hline \multicolumn{3}{|l|}{ Level of Education } \\
\hline Class X & 53 & $53 \%$ \\
\hline Class XI & 47 & $47 \%$ \\
\hline Total & 100 & $100 \%$ \\
\hline \multicolumn{3}{|l|}{ Parent's job: } \\
\hline Civil servant & 25 & $25 \%$ \\
\hline Entrepreneur & 37 & $37 \%$ \\
\hline Sales & 1 & $1 \%$ \\
\hline Private employee & 27 & $27 \%$ \\
\hline Army & 2 & $2 \%$ \\
\hline Physicians & 5 & $5 \%$ \\
\hline Home maker & 1 & $1 \%$ \\
\hline University lecturer & 1 & $1 \%$ \\
\hline Priest & 1 & $1 \%$ \\
\hline Total & 100 & $100 \%$ \\
\hline \multicolumn{3}{|l|}{$\begin{array}{l}\text { Source of } \\
\text { Information: }\end{array}$} \\
\hline School & 66 & $66 \%$ \\
\hline Family & 16 & $16 \%$ \\
\hline Health workers & 11 & $11 \%$ \\
\hline Never got information & 7 & $7 \%$ \\
\hline Total & 100 & $100 \%$ \\
\hline
\end{tabular}

The result of this research showed that almost 58\% of the participants had a weak intention to consume iron tablets, and the majority of the participants felt hesitance related to consuming iron tablets. The identification result of the participants' sources of information about iron tablets showed that 66 people (66\%) received information from their school, as many as $16 \%$ received information from their family, $11 \%$ received information from their health personnel that is from physicians and $7 \%$ never got any information about iron tablets.

The participant's characteristics showed that most of the participants were between fifteen and sixteen years old (86\%), were in class X, and most of their parents worked as entrepreneurs. Only a small percentage of the parent's jobs was related to health services.

Table 2 showed that the respondents who had parents with a low income per month $(65.2 \%)$ had a weak intention related to consuming iron tablets. Most of the participants had sufficient knowledge about anaemia and iron tablets, felt vulnerable to anaemia deficiency, and agreed that anaemia deficiency is a serious problem. However, based on the chi square test, there was no correlation between the parents' income, knowledge, perceived susceptibility, and perceived seriousness with the intention of the female adolescents to consume iron tablets. Based on the data for perceived threat, it showed that most of the participants do not feel threatened by anaemia, but it also revealed that the 
Table 2 . The correlation between factors and the intention on consuming iron tablet.

\begin{tabular}{|c|c|c|c|c|c|c|c|c|}
\hline \multirow[b]{3}{*}{ Parents income (per month) } & \multicolumn{4}{|c|}{$\begin{array}{l}\text { Female adolescent intention } \\
\text { to consume Iron tablet }\end{array}$} & \multirow{2}{*}{\multicolumn{2}{|c|}{ Total }} & \multirow[t]{3}{*}{ p value } & \multirow[t]{3}{*}{$\begin{array}{c}\text { Contingency } \\
\text { Coefficient }\end{array}$} \\
\hline & \multicolumn{2}{|c|}{ Weak } & \multicolumn{2}{|c|}{ Strong } & & & & \\
\hline & $\mathbf{n}$ & $\%$ & $\mathbf{n}$ & $\%$ & $\mathbf{n}$ & $\%$ & & \\
\hline $\begin{array}{l}\text { Low } \\
(<\mathrm{Rp} 3.296 .212)\end{array}$ & 15 & 65.2 & 8 & 34.8 & 23 & 100 & \multirow{2}{*}{0.42} & \multirow{2}{*}{0.08} \\
\hline $\begin{array}{l}\text { High } \\
\text { ( } \geq \text { Rp 3.296.212) }\end{array}$ & 43 & 55.8 & 34 & 44.2 & 77 & 100 & & \\
\hline \multicolumn{9}{|l|}{ Knowledge: } \\
\hline Lack & 2 & 100 & 0 & 0 & 2 & 100 & \multirow{3}{*}{0.46} & \multirow{3}{*}{0.15} \\
\hline Sufficient & 12 & 66.7 & 6 & 33.3 & 18 & 100 & & \\
\hline Good & 44 & 55 & 36 & 45 & 80 & 100 & & \\
\hline \multicolumn{9}{|l|}{ Individual beliefs: } \\
\hline \multicolumn{9}{|l|}{ Perceived Susceptibility } \\
\hline Not feeling vulnerable & 30 & 68.2 & 14 & 31.8 & 44 & 100 & \multirow{2}{*}{0.67} & \multirow{2}{*}{0.18} \\
\hline Feeling vulnerable & 28 & 50 & 28 & 50 & 56 & 100 & & \\
\hline \multicolumn{9}{|l|}{ Perceived Seriousness } \\
\hline Not feeling severe & 41 & 64.1 & 23 & 35.9 & 64 & 100 & \multirow{2}{*}{0.10} & \multirow{2}{*}{0,16} \\
\hline Feeling severe & 17 & 47.2 & 19 & 52.8 & 36 & 100 & & \\
\hline \multicolumn{9}{|l|}{ Perceived Threat } \\
\hline Not feeling threatened & 39 & 68.4 & 18 & 31.6 & 57 & 100 & \multirow{2}{*}{0.02} & \multirow{2}{*}{0.24} \\
\hline Feeling threatened & 19 & 44.2 & 24 & 55.8 & 43 & 100 & & \\
\hline \multicolumn{9}{|l|}{ Perceived Benefit } \\
\hline Not feeling useful & 47 & 67.1 & 23 & 32.9 & 70 & 100 & \multirow{2}{*}{0.01} & \multirow{2}{*}{0.27} \\
\hline Feeling useful & 11 & 36.7 & 19 & 63.3 & 30 & 100 & & \\
\hline \multicolumn{9}{|l|}{ Perceived Barrier } \\
\hline Feeling the barrier & 36 & 69.2 & 16 & 30.8 & 52 & 100 & \multirow{2}{*}{0.02} & \multirow{2}{*}{0.23} \\
\hline Not feel the barrier & 22 & 45,8 & 26 & 54,2 & 48 & 100 & & \\
\hline \multicolumn{9}{|l|}{ Perceived Self Efficacy } \\
\hline Do not believe in themselves & 37 & 82.2 & 8 & 17.8 & 45 & 100 & \multirow{2}{*}{0.00} & \multirow{2}{*}{0.41} \\
\hline Believe in themselves & 21 & 38.2 & 34 & 61.8 & 55 & 100 & & \\
\hline
\end{tabular}

number of participants who felt threatened had the strong intention to consume iron tablets. The data of perceived benefit and perceived barrier showed that most of the participants didn't consider iron tablets to be beneficial, and there were barriers to consuming iron tablets. The data on perceived efficacy showed that most of the participants believed that they were able to consume iron tablets beyond their beliefs about the benefits and barriers. The results of the statistical analysis revealed a significant correlation between perceived threat $(p=0.02)$, perceived benefit $(p=0.01)$, perceived barrier $(p=0.02)$ and perceived self-efficacy $(p=0.00)$ with the intention of female adolescents to consume iron tablets.

The contingency coefficient on perceived threat, perceived benefit, and perceived barriers was around 0.23 , which showed that individual belief and the intention of consuming iron tablets was not closely related. Perceived self efficacy had a contingency coefficient of 0.41 , meaning that it has a positive sufficient correlation with the intention of female adolescents to consume iron tablets.

\section{DISCUSSION}

The results of this study indicated that the factors associated with the intention of female adolescents to consume iron tablets based on HBM theory were individual beliefs, especially in relation to the components of perceived threat, perceived benefit, perceived barrier, and perceived self-efficacy. Two other components of individual other beliefs were perceived susceptibility and perceived seriousness, which did not show any correlation with the intention significance. The modification factors of the knowledge and income of the parents, which were also examined in this study, were not shown to correlate to intention.

The intention of female adolescents to consume iron tablets in this study shows that the majority of the participant's intentions were at a weak level. In this study, it was found that the majority of the respondents had a good level of knowledge about anaemia and iron tablets, but generally did not have a strong intention for consumption. This could happen because the knowledge possessed by the adolescents does not provide enough information, so then the teenagers are motivated to consume the iron tablets (Compaore et al. 2014). Research in Vietnam on the factors related to the consumption of supplements, including iron, shows that the intention of women to take supplements, especially iron, is still low outside of pregnancy (Nechitilo et al. 2016). Research carried out in Tigray, Ethiopia, revealed that adolescents do not consume iron tablets due to public awareness, misinterpreting that iron tablets are contraceptive pills, religious and moral influences, and a lack of trust in the value of the iron tablet (Mulugeta et al. 2015). Some studies suggest that anaemia prevention programs in female adolescents were more effective when school-based 
(Mulugeta et al. 2015; Rakesh et al. 2015). Considering that, in this study, it was also found that most of the respondents get their knowledge about anaemia at school, thus health workers from both primary health services and school health units need to collaborate in school-based anaemia prevention programs.

The results of this research showed that most of the respondents had not felt threatened by anaemia. However, for the respondents who considered anaemia to be a threatening thing for them, the intention level was strong. The positive correlation between perceived threat and intention in this research was in line with the results of a previous study by Park (2011), which stated that perceived threat was significantly associated with behavioural intention. This is also consistent with the results by Hubbard (2017) which revealed that someone facing a high perceived threat will have more desire to find information about the situation at hand. However, in the contingency coefficient between perceived threat and intention, there was a low correlation. This happened because according to Glanz et al. (2015), perceived threat is a combination of perceived susceptibility and perceived seriousness where the perceived susceptibility must be strong enough to produce behavioural changes. From the statistical analysis, it was revealed that in this research, perceived susceptibility and perceived seriousness were not significantly related to the intention of iron tablet consumption.

The other significantly positive result in this study was the correlation between perceived benefit and perceived barrier with iron tablet consumption intention. Most of the respondents indicated that they did not feel that consuming iron tablets would give them more benefits. However, when viewed from the percentage of the number of respondents related to the perceived benefits, it appears that the respondents who do not feel that they would benefit had a low intention. Research related to anaemia prevention programs in India conducted by Malhotra (2015) reveals the fact that the rejection by adolescents and their parents was associated with iron tablet supplementation in adolescents. This was because the administration of iron tablets causes side effects that are not well-known by teenagers and their parents. Regarding health behaviour and puberty, the perceived benefits have proven to be one of the strongest predictors that can change adolescent health behaviour for the better (Shirzadi et al. 2016). If there is a high level of perceived benefit followed by a low perceived barrier, then the better the behaviour that is displayed (Shirzadi et al. 2016). Perceived barriers are also said to be a cost of implementing new behaviour (Araban et al. 2017). Perceived barrier can also come from the environment and the people around (Park 2011). From the questions on perceived barriers, it was revealed most of the participants were reluctant to consume iron tablets because of its unattractive packaging and the shape of the iron tablets (64\%), and also because most of their friends did not consume them (58\%). Some of them did not like the taste of the iron tablets (44\%). For teenagers, environmental influences can be very influential, especially when from their peers. Most teenagers will try to adjust themselves to their social group, which can be about socialisation, style of dress, and even the food that they consume. The failure to adjust can make teenagers feel alien to their environment.

This study has proven that there was a significant correlation between perceived self-efficacy with the intention of iron tablet consumption. The correlation tests showed that there was a close relationship at the medium level between perceived self-efficacy and the intention of female adolescents to consume iron tablets $(r=0.41)$. A similar study in Indonesia about perceived self-efficacy and perceived benefits showed that there was a significant correlation between perceived self-efficacy and intention, while perceived benefit showed no correlation (Annisa \& Nurmala 2018). Gerdawati (2016) analysed the factors related to female adolescent attitude in relation to the prevention of cervical cancer by HPV vaccination at senior high schools in Lampung, which found similar result explained that there was a significant correlation between self-efficacy against the attitude present in relation to the prevention of cervical cancer. Her argument was that the result may be caused by the existence of peer support and reliable information. Another study about predicting intention to take protective measures during hazing in Singapore revealed that self-efficacy was associated with the intention to take protective measures during hazing (Lin \& Bautista 2016). A meta analysis study by Sheeran et al. (2016) suggested that a modification on attitudes, norms, and self-efficacy can change health behaviour effectively. A study of behavioural intention when conducting a health examination recommends that self-efficacy is the strongest factor affecting a person in relation to carrying out a health check, followed by knowledge about health. The study also mentioned that the various factors that exist in HBM that can influence behavioural intention. Self-efficacy is one factor that can directly influence behavioural intention and other perceived factors (Huang et al. 2016). Self-efficacy is an internal mental process in a person that describes a person's ability to control his behavior (Glanz et al. 2015). A person who is able to control his behaviour will increase his intention to carry out a healthy behaviour.

\section{CONCLUSION}

From the results, we can conclude that perceived threat, perceived benefits, perceived barriers and perceived self-efficacy is associated with the intention of female adolescents in relation to consuming iron tablets. Perceived self-efficacy is the most correlated factor related to producing intention in female adolescents to consume iron tablets. 
In relation to the intention of female adolescents, it is recommended that the government, through its health department, runs a sustainable program distributing iron tablets for female adolescents, which includes comprehensive health education and a counseling component to improve self efficacy. It is also important that the iron tablet program collaborates with schools to achieve a better outcome.

\section{REFERENCES}

Annisa, F.N. \& Nurmala, I., (2018). Influence Perceived Benefit and Perceived Self Efficacy with Intention of Adolescent girls in Consuming Fe Tablet. Indian Journal of Public Health Research \& Development, 9(4), p.326. Available at: http://www.indianjournals.com/ijor.aspx?target =ijor:ijphrd\&volume=9\&issue $=4 \&$ article $=063$ (Accessed: December 27, 2017).

Araban, M., Baharzadeh, K. \& Karimy, M., (2017). Nutrition modification aimed at enhancing dietary iron and folic acid intake: an application of health belief model in practice. The European Journal of Public Health, 27(2), p.ckw238. Available at: https://academic.oup.com/eurpub/articlelookup/doi/10.1093/eurpub/ckw238 (Accessed: December 27, 2017).

Compaore, A. et al., (2014). "There is Iron and Iron..." Burkinabè Women's Perceptions of Iron Supplementation: A Qualitative Study. Maternal and Child Health Journal, 18(8), pp.1976-1984. Available at: http://link.springer.com/10.1007/s10995-0141443-x (Accessed: December 27, 2017).

Gerdawati, A.S., (2016). Analisis Faktor yang Berhubungan dengan Sikap Remaja Perempuan dalam Pencegahan Kanker Serviks oleh Vaksinasi HPV di SMA Sidomulyo Lampung. Surabaya: Universitas Airlangga. Universitas Airlangga.

Glanz, K., Rimer, B.K. \& Viswanath, K., (2015). Health Behavior: Theory, Research, and Practice, Wiley. Available at: https://books.google.co.id/books?id=PhUWCgAA QBAJ. (Accessed: December 27, 2017).

Huang, H.-T. et al., (2016). Structural Factors Affecting Health Examination Behavioral Intention. International Journal of Environmental Research and Public Health, 13(4), p.395. Available at: http://www.mdpi.com/16604601/13/4/395 (Accessed: December 27, 2017).

Hubbard, A.K., (2017). Relationship help-seeking and the health belief model: how the perception of threats and expectations are associated with help-seeking behavior. Available at: http://krex.kstate.edu/dspace/handle/2097/38198 (Accessed: December 27, 2017).

KEMENKES RI, (2014). Permenkes RI No 88 Tahun 2014 Tentang Standar Tablet Tambah Darah Bagi Wanita Usia Subur dan Ibu Hamil, Available at: chrome-

extension://oemmndcbldboiebfnladdacbdfmada $\mathrm{dm} / \mathrm{http}$ ///sinforeg.litbang.depkes.go.id/upload/ regulasi/PMK_No._88_ttg_Tablet_Tambah_Darah_. pdf.

KEMENKES RI, 2017. Pusat Data dan Informasi: Situasi Kesehatan Reproduksi Indonesia. , p.8.

Kementrian PPN/BPPN, (2014). RENCANA PEMBANGUNAN JANGKA MENENGAH NASIONAL2015-2019, Kementerian PPN/BPPN.

Lin, T.T.C. \& Bautista, J.R., (2016). Predicting Intention to Take Protective Measures During Haze: The Roles of Efficacy, Threat, Media Trust, and Affective Attitude. Journal of Health Communication, 21(7), pp.790-799. Available at: https://www.tandfonline.com/doi/full/10.1080/ 10810730.2016 .1157657$.

Malhotra, S. et al., (2015). Challenges in scaling up successful public health interventions: Lessons learnt from resistance to a nationwide roll-out of the weekly iron-folic acid supplementation programme for adolescents in India. The National medical journal of India, 28(2), pp.81-5. Available at:

http://www.ncbi.nlm.nih.gov/pubmed/2661215 2 (Accessed: December 27, 2017).

Mulugeta, A. et al., (2015). Examining Means of Reaching Adolescent Girls for Iron Supplementation in Tigray, Northern Ethiopia. Nutrients, 7(11), pp.9033-9045. Available at: http://www.mdpi.com/2072-6643/7/11/5449

Nechitilo, M. et al., (2016). A Qualitative Study of Factors Influencing Initiation and Adherence to Micronutrient Supplementation Among Women of Reproductive Age in Vietnam. Food and Nutrition Bulletin, 37(4), pp.461-474. Available at: https://doi.org/10.1177/0379572116647830.

Park, D.-Y., (2011). Utilizing the Health Belief Model to predicting female middle school students' behavioral intention of weight reduction by weight status. Nutrition research and practice, 5(4), pp.337-48. Available at: http://www.ncbi.nlm.nih.gov/pubmed/2199452 9. (Accessed: December 27, 2017).

Rakesh, P.S. et al., (2015). Anaemia among schoolchildren from southern Kerala, India: A cross-sectional study. National Medical Journal of India, 28(5), pp.225-227.

Sheeran, P. et al., (2016). The impact of changing attitudes, norms, and self-efficacy on healthrelated intentions and behavior: A meta-analysis. Health Psychology, 35(11), pp.1178-1188. Available at: http://doi.apa.org/getdoi.cfm?doi=10.1037/hea0 000387. (Accessed: December 27, 2017).

Shirzadi, S. et al., (2016). Determinants of puberty health among female adolescents residing in boarding welfare centers in Tehran: An application of health belief model. Medical journal of the Islamic Republic of Iran, 30(432), p.7. Available 
http://www.ncbi.nlm.nih.gov/pubmed/2821059

7. (Accessed: December 27, 2017).

WHO, (2011). Prevention of iron deficiency anaemia in adolescents, World Health Organization, South-
East Asia Regional Office. Available at: http://www.searo.who.int/entity/child_adolesce nt/documents/sea_cah_2/en/ 